\title{
Cult of Reason and Cries of Rage
}

\author{
Irving Louis Horowitz
}

Published online: 24 March 2011

(C) Springer Science+Business Media, LLC 2011

James T. Kloppenberg, Reading Obama: Dreams, Hope, and the American Political Tradition. Princeton and Oxford: Princeton University Press, 2011. 302pp. \$24.95. ISBN-10: 0691147469; ISBN-13: 978-0691147468

Dinesh D'Souza, The Roots of Obama 's Rage. Washington, D.C.: Regnery Publishing Inc., 2010. 258pp. \$27.95. ISBN-10: 1596986255; ISBN-13: 978-1596986251

Just as presidential leadership in a democracy does not stand still, so too, do academic interpretations do their devilish best to keep pace. Classic statements on the subjects seem to be having a revival, particularly Clinton Rossiter's Constitutional Dictatorship and Arthur Schlesinger's Imperial Presidency. Both were inspired, in part at least, by presidential excesses in times of crisis. I begin this review with Rossiter's recollection of the founding fathers. "Is there in all republics this inherent and fatal weakness? Must a government of necessity be too strong for the liberties of its people, or too weak to maintain its own existence?" (Abraham Lincoln, Message to Congress July 4th, 1861) The modern version of Mr. Lincoln's question: "can a democracy fight a successful total war and still be a democracy when the war is over?" will be answered affirmatively by the incontestable facts of history.

Contemporary presidential conduct calls forth writings that address present realities. In this context two quite disparate, indeed near opposite readings, of the Obama presidency, at least to this point in time, are The Roots of

I. L. Horowitz $(\bowtie)$

Rutgers University,

35 Berrue Circle,

Piscataway, NJ 08854, USA

e-mail: ihorowitz@transactionpub.com
Obama's Rage by Dinesh D'Souza, the newly appointed president of King's College in New York City, and Reading Obama by James Kloppenberg, a distinguished professor and chair of the History Department at Harvard University. Two more different institutions of higher learning could hardly be located, and two more different interpretations of the same leader are evident in contemporary political discourse. Upon his academic appointment, D'Souza said plainly that "If we do our job, and our students do their job, they will graduate from King's as dangerous Christians. Dangerous because they are spiritually equipped and intellectually equipped." A far different tradition, Harvard pragmatism of an earlier age, inspires Kloppenberg. That tradition, however provisional, "provides sufficient stability to enable us to move forward, as members of communities located in history, aware of our traditions and self-consciously attempt to realize the ideals we choose to keep alive as our guides." (80) Arguably, these two views point to polarization within the academy no less than the polity; to reliance upon religion in the first instance and national tradition in the latter instance. Whether this divided vision is good for students or even politicians is a topic for a more ambitious occasion.

Here we simply wish to examine how such diverse ideological underpinnings inform academic study of President Barack Obama. His election in 2008 has stimulated traditional concerns on the character of democratic leadership. One such legitimate concern from a classical liberal viewpoint is whether the office of the presidency is able to retain a democracy if the office itself becomes too powerful and remote from the electorate. Institutional changes - the decline of traditional political parties, the rise of media driven candidates, the sheer growth in size of the Executive branch of government, the emergence of nonelective officials as "czars," the military becoming itself more politicized and hence increasingly influential in 
foreign policy, are all cited as threatening the tradition of republican values. Most of all there is a concern about threats posed by the transformation of the White House into a platform of charismatic extremism and bureaucratic lawlessness. While academic recommendations in these volumes are extremely modest, based on celebratory elements as "Deliberation Day, a National Endowment for Journalism, or new canons of Military Ethics" (187), such observations on the present regime merit attention: The problem posed by Bruce Ackerman is that the very ideology which governs the current presidency inhibits a return to strict constitutional democracy.

A different effort to address this analytic weakness is found in Juan J. Linz's recent essay on "The Perils of Presidentialism." Written in a comparative international perspective, Linz deals with the paradoxes of presidentialism. "On the one hand, such systems set out to create a strong, stable executive with enough plebiscitary legitimation to stand fast against the array of particular interests represented in the legislature... On the other hand, presidential constitutions also reflect profound suspicion of the personalization of power: memories of kings and caudillos do not dissipate easily." In the vortex of choices between presidential and parliamentary systems, recent theories of political science locate the struggle between rigidity and flexibility evident in the current malaise. Under such conditions, the law provides for some semblance of equilibrium. Such analysis indicates probabilities and tendencies, not determinisms in presidential choices.

Parliamentary systems can exhibit grave crisis even breakdown, but they are a primary bulwark against unbridled presidential excesses. In the final analysis, however, all regimes depend for their preservation upon the support of society at large, and must rely on a notion of a "public consensus" that can be achieved only through legitimate authority. It is only that power which is acquired through lawful and democratic means. Such an approach simply returns the problem to its base: the nature of rule and rulers. In this circularity of reasoning, in which we return to the social system and the problem of presidential rule as such, we see a critical problem in European political thought. Democratic rule becomes an entity rather than a process. In an American context at least, it is not so much a search for general theory, but the specifics of rule as such that requires answers to concerns being raised by very able analysts of general theories and broad system such as the position taken by Juan Linz.

Able commentators such as Gordon F. Seib, in The Wall Street Journal, have sensed that President Obama is not so much an ideologue, but a head of state caught in a web of multiple aims. Seib notes that it is like "watching a leader struggling with wildly contradictory demands and impulses." The severe political cross currents in which a
President is enmeshed harkens back to the nature of campaign pledges, but demands attention that could not possibly be imagined in the rhetorical heat of partisan politics. What is crucial with respect to the books under consideration is a distinction between the relative simplicity of right and wrong during a campaign, and the far more difficult matter of governing after the election rhetoric is replaced by complex and difficult decisions that require more than appealing for "change" or "hope." Huge quantitative issues require attention-from the amount of funds needed or available for bail outs, the number of troops needed to secure a victory or at least a stand-off in overseas combat, the number of years required to fully fund advanced medical care - these require a presidential seal of approval that may support or frustrate policy mandates. The inevitable moral and legal puffery of autobiography can scarcely serve as the basis for on the ground evaluations of presidential performance. Books that appear several years into an administration grounded in general theorizing simply are of little use or consequence in specific contexts that are either unexpected or unpredictable during a campaign. This tendency to underestimate events on the ground and overestimate personal histories is a mistake made by those who think of political leadership as psychological occurrences rather than collective appraisals made by many people in a wide range of board rooms all of whom report, and sometimes influence, presidential leadership.

In his Preface to his masterful trilogy on Benjamin Franklin, the late Carl Van Doren noted "Franklin, the most widely read of autobiographers, is best known from his Autobiography, and therefore too little known." What Van Doren wisely calls to our attention is that early works of a rising personage cannot possibly do justice to the years of maturity and authority of that same individual. The absence of such awareness is precisely the core problem in both of these Obama volumes: Based as they are on Dreams from My Father: A Story of Race and Inheritance, (1995); The Audacity of Hope: Thoughts on Reclaiming the American Dream (2006) and Change We Can Believe In: Barack Obama's Plan to Renew America's Promise (2008) any sense of the actual accomplishments of the first half of the administration is hard to discern. In a closing chapter Kloppenberg hurriedly tries to address realities, while D'Souza makes a strong effort to integrate Obama's selfreflections with his current political activities. And both are persuasive. A case can be made for Obama as continuator of classic American liberalism as well as Obama as an anticolonialist. But such extrapolations from autobiography really just confirm the ambiguity of his leadership, especially when examining the first 2 years of Obama policies. It is after all the role of analysis-historical or political - to explain rather than cajole or to exonerate. 
The D'Souza book along with Kloppenberg's left counterpart are both victims of a curse in the contemporary. Both reduce the study of presidential leadership to a single variable - in this case the driving source for power as such. Ultimately this type of analysis lodges issues not on regimes, parties, or people; but in the character of the person, or as D'Souza would have it: "Obama's Private War..."The Outsider"..."Putting on the Mask"...Becoming Barack." In this way, political science is reduced to political psychology - a branch of leadership that comes to substitute for the big tree, and explanation becomes a matter of personality. "Obama converts his poor treatment at a restaurant into a case study in the workings of neocolonialism. If all this seems like multicultural mind games, we have to realize that Obama does not see it that way at all. To him these episodes are all part of a great drama." The great flaw in such commentaries on everything from Obama's attendance at the Reverend Jeremiah Wright's Church in Chicago, to his trip to Kenya is not simply "an application of Obama's ideology to his presidential run as well as to his domestic and foreign policy," (111) it is an application of the book's thesis, to wit: "becoming Barack" is becoming an anti-colonialist. The reader is left in doubt whether to respond to such a commonplace revelation by opposing the presidential Third World ideology or worse, simply supporting the blessings of colonialism.

This type of analysis necessarily omits a variety of alternative explanations. What is lost is the sense of the present, of how one can grow up with all kinds of animosities and antagonisms as a young person, and in the crucible of quotidian struggle, come to recognize weaknesses in such a line of reasoning. The decisionmaking one undertakes as president, the context of interactions and forces known at the level of the exercise of authority is quite different than how one starts life. This genetic fallacy, of inferring behavior from inherited contexts is so central to D'Souza, that it is virtually impossible for him to examine with dispassion such elements in Obama's leadership as agreement to support hefty troop operations in Afghanistan, or for that matter, to move slowly in recognition of the Cuban communist regime until democratic norms are agreed to and set in place. That such consideration may be due to hardheaded political liabilities of the costs of opposing an American presence in Afghanistan or support for immediate recognition of the Castro regime is entirely reasonable. Indeed, multiplying such immediate factors to policy toward the more than 200 nations with which the United States must continually re-evaluate policies should caution against heavy-handed reductionism in judging presidential performance.

Then again, the opposite error of seeing policy as part of a larger liberal political tradition does not help matters. It simply presumes Obama is working out an ideology, only of a more pleasant and humane sort. This is of course what we find in Kloppenberg's book. He writes that "Obama deliberately tied the principles under girding the peacekeeping efforts of the United Nations to the 'law of love' that has "always been the core struggle of human nature", (241). Such abstract theorizing presumes a unity of behavior in the political realm that may characterize the perfect dictatorship, but clearly violates any sense of the democratic character of American decision-making, and jurisprudence that Obama is committed to, indeed required to follow by law - a position with which by background and training he is most comfortable.

This belief in Obama's overweening search for personal power opens the door to secondhand analysis glossed over by using autobiography as the sole source of information. Still worse, both books cater to pseudo-populist biases. The constant theme of neo-colonialism as the "root of Obama's rage" is transparently silly. Should he or any candidate for the highest office in the American land argue the case for colonialism? To even ask the question, whether in relation to the history of Europe in Africa, in which Great Britain and France divided a continent, or of the United States in Latin America is to move back in time to an era of the Monroe Doctrine or carrying a Teddy Roosevelt "big stick." Issues of nation-building, economic development and sovereignty have simply moved beyond such a stage of history. The reader must necessarily infer the conservative bias of D'Souza and the liberal bias of Kloppenberg, thus making them participants in the drama of the presidency as such. Indeed, the consequences are a cult of personality for Kloppenberg, who likes Obama and a portrait of Obama as bitterly alienated from the political process by D'Souza who loathes the Obama administration.

We are steadily reminded of D'Souza's own standing in the Washington DC community-or at least his sense of self. "Obama may not join me, but as an Indian myself who has greatly benefited from this colonial legacy, I am quite willing to give two cheers for colonialism" (209). But even D'Souza withholds the third cheer "in deference to my ancestors." He is entitled to what might even be thought of as a courageous alternative to the anti-imperialism that dominates present day thinking, but to turn his book into a jeremiad against the president hardly convinces. By the same token, Kloppenburg's valiant effort to convert Obama's life as a paean of "many echoes from the American past, both its origins and recent decades of intellectual as a cultural upheaval" (264) results in little more than apologetics. He makes a happy pastiche of founding fathers, without making clear that struggles between Jefferson and Adams were as real and as bitter among the founders themselves as their followers. To convert the influences upon Obama to a happy, albeit 
discordant family squabble is simply apologetics unrelieved by reality, much as D'Souza offers up a meal of animosities unrelieved by reality.

Such views from inside the DC Beltway or in the case of Kloppenburg's visions overlooking Harvard Square have the unanticipated consequence of adding to the American people's frustrations with the political process as such. It does not advance the cause of public debate, or "affirm the process of continuous and open-ended experimentation" (265) so much as cast doubt on the legitimacy of the political system, or the "principle of democracy." Such writing, whether by design or accident, only increases the sense of alienation and separation of the American people from the political process. An earlier generation of political history for all of its pretentious assumptions explained the past (rather well) and predicted the future (rather poorly) so as to educate the public on the causes and consequences of elected and appointed American officials.

Figures such as Clinton Rossiter, Aaron Wildavsky, Daniel Bell, Harold Lasswell and a current group of political scientists mentioned at the head of this review have been replaced by a cluster of self-promoting media specialists, who use either criticism at one end or celebration at the other to enlist a captive political audience on the Right and Left. They impose a crude sort of imagery that ignores the culture of political science in favor of yellow dog journalism at one end or a cult of personality at the other. Within the span of several months prior to the mid-year elections of 2010, we have been feted with Crimes against Liberty (David Limbaugh), Bought and Paid For (Charles Gasparino), and Conduct Unbecoming (Robert Patterson). This series of blasts-against a presumed dictator, a sell out to Wall Street, and a commander in chief prepared to dismember the armed forces-has given the public precious little by way of intelligent and informed debate. Indeed, such efforts serve to distance public opinion from the political process. But they also increase the risks of demagoguery whether by accident or design. This has the opposite impact intended by either liberal or conservative commentators, encouraging participation in the political process as a street action. Reductionism competes with abstractionism in these two well intentioned efforts at serious surveys of Obama's writings. It is difficult to see either as satisfying the need for a full accounting of the Obama administration at its halfway point in office.

D'Souza sees the world in terms of Third World power rankings, first among many factors-including race, religion, nationality, class, education, and politics, as an end in itself as well as a means to both lower and higher ends. Such analysis treats presidential politics, and that included the treatment accorded to President Bush no less than President Obama, as a serious injury to the culture as such. There is a partisan presumption that a president, any sitting president, is guilty until proven innocent. This is a world of intellectual savagery intended to save America from falling from original founding father grace but ends up condemning America to decadence. It is time to stand firm for political science as an ethic based upon human experiences in the art of governance. We must make it clear that it came into prominence to help us move beyond self-promotional and ideological driven op-ed pieces that dominate the media more thoroughly than at any time past.

By the same token, partisan assaults cannot be answered by reverential defense of a particular elected presidentactions and performances that are only now in the position of being formulated, and of two autobiographical memoirs and a pre-election set of platform guidelines. Kloppenberg essentially offers a reassuring guide to the perplexed, or those who have any doubts that Obama's economic policies, wealth and welfare legislation, or approach to international relations in the Middle East, are well intentioned. To be sure, Kloppenberg expresses doubts about Obama's approaches to war in Afghanistan and peace prizes in Norway. But these emerge as afterthoughts to a cult of a hero worshiping displayed as a whole. The subtitle of his book itself is a parody of Obama's rhetoric: "Dreams, Hope, and the American Political Tradition." But like all mantras, these have been overtaken by the hard work that goes into the actual conduct of a democratic system - in which democracy is viewed as a series of processes embedded in human fables and foibles presented as principles.

Those who embody democratic values in their analysis of political leadership must also be prepared to embrace democratic systems as an imperfect but necessary instrument of rule. That signifies the need for academic pundits to examine with care and civility the tripartite nature of the American mosaic. The Obama presidency, like any previous presidency, must interact with the executive, legislative and judicial branches. Kloppenberg is all too eager to pursue such interactions, whilst D'Souza is no less eager to deny the prospects. In that special sense, it might be argued that both of these works provide valuable footnotes to Barack Obama's own travels to the past. Only if the system itself is put in jeopardy by a president, or a congressional whip, or for that matter, a court justice so powerful as to undercut two centuries of decision-making, should such excessive reliance upon autobiographical rationalizations become an imperative for understanding the course of a regime. I can detect no such serious threat at this moment in time, history, and nation. Let us hope with Kloppenberg and pray with D'Souza that such a time never descends on the American nation. 


\section{Further Reading}

Ackerman, B. 2010. The decline and fall of the American Republic. Cambridge, MA: Harvard University Press.

D'Souza, D. 2010. Dangerous Christians. First things. Whole Number 207, November, pp. 61-62.

Horowitz, I. L. 2010. Legalism as an executive ideology: Foundations of Barack Obama's leadership style. Perspectives on Political Science, 39(3), 160-166.

Linz, J. J. 2010. The Perils of Presidentialism. In L. Diamond, M. F. Plattner, \& P. J. Costopoulos (Eds.), Debates on democratization. Baltimore: The Johns Hopkins University Press.
Rossiter, C. 2002. Constitutional dictatorship, p. 14. New Brunswick and London: Transaction Publishers.

Seib, G. F. 2010. The missed opportunities of 2008. In The Wall Street Journal, September 14th, p. A2.

Van Doren, C. 1938. Benjamin Franklin (Preface, pp. v-ix). New York: The Viking Press.

Irving Louis Horowitz is Hannah Arendt professor emeritus of sociology and political science at Rutgers University. He is author of Behemoth: Main Currents in the History and Theory of Political Sociology, Ideology and Utopia in the United States, 1956-1976; and coauthor, with Seymour Martin Lipset, of Dialogues on American Politics. 